NBER WORKING PAPER SERIES

THE ALLOCATION OF TIME:

YOUNG VERSUS ELDERLY

HOUSEHOLDS IN JAPAN

Tadashi Yamada

Tetsuji Yamada

Working Paper No. 4386

\author{
NATIONAL BUREAU OF ECONOMIC RESEARCH * \\ 1050 Massachusetts Avenue \\ Cambridge, MA 02138 \\ June 1993
}

This paper is a product of research programs funded by the Ministry of Education, Science and Culture of Japan (gtant \# 02630021 in 1990 and Grant \# 03630025 in 1991), the Nomura Foundation (1990 and 1991), and University of Tsukuba. We are indebted to Professors Michael Grossman, Bernard Okun, John D. Worrall, and participants of Economic Workshop at the Institute of Socio-Economic Planning of the University of Tsukuba for their helpful comments on an earlier draft of this paper. We are aiso grateful to Keirei Ki for her research assistance. Any opinions expressed in this paper as well as any errors which remain are ours. This paper is part of NBER's research program in Labor Studies. Any opinions expressed are those of the authors and not those of the National Bureau of Economic Research. 
NBER Working Paper \#4386

June 1993

\title{
THE ALLOCATION OF TIME: \\ YOUNG VERSUS ELDERLY \\ HOUSEHOLDS IN JAPAN
}

\begin{abstract}
Our study shows that the household production theory illuminates the behavior of households in the allocation of time and consumption expenditures. Among the noteworthy findings derived from our data, the various household non-market time allocations (consequently, market labor supply) cannot be separated from consumption expenditures. An increase in market wage rates for both young and elderly houscholds reduces their time spent on household nonmarket activities, such as child care, medical care, and listening to the radio and watching TV. The high opportunity costs of waiting at the hospital ciearly discourage working people from visiting the hospital. These results show not a few similarities between the houschold non-market time allocation in Japan and that to be found in the U.S.
\end{abstract}

Tadashi Yamada

University of Tsukuba

Institute of Socio-Economic

Planning

Tennodai 1-1-1, Tsukuba-city

Ibaraki-ken, Japan 305

and NBER
Tetsuji Yamada

Rutgers University - Canden

Department of Econornics

Canden, NJ 08102

and NBER 


\section{Introduction}

Human time $1_{g}$ one of the moat scarce resources. For understanding the way this acarce resource 1s allocated to gatiofy competing human desires, we should look at the household's time allocation on labor eupply as merely one of various activities in conjunction with household production (Becker 1965)."

Allowing for the fact that the traditional consumer demand analysis puts great emphass on the behavior of hougehold consumption expenditures, some recent empirical gtudies are aucceasful in bridging the gap between the consumption expenditure atudiee and the hourehold production studie日 (Barnett 1979, Kooreman and Repteyn 1987, and Biddle and Hamermesh 1990). Although these atudien provide ugeful observations about hourehold time allocation, when the various hourehold coneumption expenditurea axe analyzed, the household non-market time activities are dealt with as a eingle entity, $i . e .$, leloure. On the other hand, when the different non-market time activities are atudied, the congumption expenditures are treated as an aggregate comodity.

To be more consigtent with theory and congequently to underatand household economic activities more deeply than the traditional demand atudy, household non-market tine activities,

1 See Juater and stafford (1991) for an excellent arvey of literature on the allocation of time.

2 The results are: Barnett (1979) rejects the separability between consumer's labor aupply and consumption of market gooda; kooreman and Kapteyn (1987) verify variations in the time allocation of hougehold non-market activities in response to changes in the real wage rate; and Biddle and Hamermeah (1990) focur on a major hourehold time allocation, i.e., sleep, and identify wage effecta on leeping and waking non-market time for men and on market and waking non-market time for women. 
rather than being aggregated a a single entity of leilure, need to be simultaneously analyzed with hougehold congumption expenditures in a gyotem of demand functiong. This approach allows consiatency with standard aconomic hypotheses auch as integrability. separability, and homogeneity. With appropriate parameter restrictione in the ayatem, we are able to test for oparability in hougehold non-market time activit1es."

Furthermore, the aforementioned empirical findinge on hourehold time allocation should be verified for different culture日. For example, in a country like Japan, people of different ages and different gender geem to have distinct roles in the hougehold and are likely to behave differently in response to changer in avallable economic incentiver.' In addition to our concern with International comparisong regarding the household allocation of time, we focus epecifically on some of the social 1ssueg currently being debated in Japan.

First, the rate of reproduction among young couples has declined oharply in recent yeara; the total fertility rate, which Is the number of live births by a woman during her reproductive period, was 4.40 in 1948, and 1.75 in 1900 . The most recent avaliable flgure is 1.53 in $1990^{3}$ How, then, do young Japanese

3 The excellent and comprehenaive Ilterature on a aystem of consumer demand functiona to review is Brown and Deaton (1972), Diewert (1974, ch.3), Barten' (1977, ch.2a), Lau (1977, ch.2b), Deaton and Murllbauer (1983), Deaton (1986), and Blundell (1988).

- The labor market in Japan atill keepo the traditional employment ayatem although the Equal Employment Opportunity Law went into effect in 1986 (Edwarde 1988).

5 The Current Conditiona of Women'a Labor, Miniatry of Labor, 1991, P. 887: "Fujin Roudou no Jitsujyo" in Japanese. 
households use thelr time after having chooen a smaller family size ever than before? second, it is often ald, gomewhat cynically, that people must watt in a "3-hour" queue at the hospital to recelve a "3-minute" medical treatment. A long queue at the hoapital reflects a high shadow price of feceiving medical care. The high opportunity coote of waiting at the hoopital will discourage working people from visiting the hospital. We consequently pose the following question. How responsive is hospltal vioiting time to changing economic incentives?

The organization of the subaequent sections is as follows: we report the evidence from the survey of the allocation of time over the period from 1976 to 1986 in section II; our analytical framework is presented in section III; section IV reports the empirical findinga; and finally section $v$ drawg our conclusion of this study. 
II. Evidence from the survey on Allocation of Time

The cross-gectional data for citiea with prefectural government on tims spent on dally activities by males and females at different age groupe In 1976, 1981, and 1986 are to be found in Eagie Survey on Social Life, published by the Bureau of statistica, office of the Prime Miniater of Japan.

of "Hours and Minutes per Day spent on Activitieg" in Tables I-(1) and (2), the reported time allocations are weekly averages of tIms per day. 'Table I-(1) shows the young households' (males and females aged 25-39) allocation of time apent on work, aleep, child care, medical care, and Radio \& TV (1iatening to the radio and watching TV). The time activitiea of elderly households (malea aged 65 and over, and females aged 60 and over) are 1 isted in Table I(2) .

The reagons for choosing these different age groupa for analyoi, in our study are that the former young age group has two distind characteriaties: the members of thio group are in the middle of determining the size of their families; and most of the males in that age group are very likely to be in the labor market. on the other hand, the latter elderly group at the age of 65 years old ia likely to be retired from the labor market and to have btarted recelving soctal aecurfty retirement benefita. Furthermore, the payments for medical care of members of this group at the hoepltal are mootly covered by the public medical ingurance for elderly people." Hence, we coneider that these different age groups

t To be more epecific, elderly people aged 65 through 69 , who are confined to bed, and those aged 70 or more are covered by this health care progran. 
are most likely to behave differently in responge to changea in economic opportunitiea.

Since the figures reported in the Tables are aelfexplanatory, we mainly discuse the time allocations of males and females aged 25-39 in Table I-(1). The male market dally working hours rose from 7 hourg 22 minutes a day in 1976 to 7 hourg 49 minuteg in 1986.7 since these reported flgures are weekly averages of 7 days, if Japanese people hypothetically work the same amount of hourg for 5 days a weok eimilar to the western standard, their working hourg are nearly 10 hours a day on average."

As regarda eleeping hours, maled "with a fob" sleep shorter hours than males "without a fob", roughly by 30 minute a day." Such a large difference, however, vanisher in the case of females. Males eleep longer hours a day than females in Tapan. As is to be expected in Japan, males, regardless of thefr attachment to the labor market, apend little time on child care, while females spend a aubgtantial amount of thelr time on providing this care. Those females "without a fob" spend twice as much time or more each day

7 The most recent figures on the average monthly working houra per worker in the manufacturing industry in 1990 are 178.2 hourg in firms with 30-99 workers; 174.8 hours in those with 100-499 workers; and 177.0 houre in those with 500 workers or more (White Paper on Labor, Minlatry of tabor, 1991, p. 287: "Roudou Hakubyo" in Japanese). Note that the average monthly working hours are not age and male speciflc, but induatry specific values. Hence, these average monthly working hourg are somewhat different from the male' a average dally working hours reported in the text.

- 9.6 percent of the firme with 30 or more workerg have a regular weekly 2-day off echedule in 1989, which cover 36.9 percent of total employment in industries (The current conditions of Women's Labor, Miniatry of Labor, 1990, p. B94).

- Biddle and Hamermesh (1990) report that "Time spent oleeping ig invergely related to both the wage and time apent in the labor market ( $p .941) . n$ 
on child care than working females, who epend three hours or so on average. 10

Concerning medical care, malea "with a job" have much less time spent on medical care than males "without a job", while this 1a not so for femaleg. ${ }^{11}$ To account for thia difference in medical care for males, two testable hypotheges may bo offered: the firgt one, for which we actually make a test in this atudy, is that males In the labor market face high opportunity cogte in visiting the hospital and hence they vialt less often as their economic opportunitieg rise, while the income effects work toward more medical care; and the becond one 1 s that males who are not in the labor market are more likely to be 111, and the "not in the labor forcer may be an indicator of poor health atatur. Hence thoge out of the labor force spend more hours on medical care than those in the market. In this gecond cage, economic opportunities, e.g., their potential market wage rates, will exert little influence on their choice of vistting the hospital, Finally, both malea and femalea "without a Job" do epend much more time on Radio $E$ TV (1.e., ligtening to the radio and watching TV) than those "with a job". This phenomenon again seems to be Indicative of the difference in their economic opportunitiea. In aum, there exist marked behavioral differences in the allocation of time between young persons "with a job" and those "without a job" and also between males and femalea of the same age group. These observations

10 Since a baby-gitter syatem 1 a not popular in Japan, working females are likely to be elther oending their children to nurserieg or living with their parents, who take care of children.

11 The Bagle Survey of Social Life does not include patiento in the hoapital in the sample. 
with respect to young people are almost duplicated for elderIy people as reported in Table I-(2). Consequently, we consider it extremely valuable to clarify empirically to what extent their time allocation are responstve to changea in their economic opporturities, and to Identify their behavioral differences in the allocation of time. 
III. Analytical Framework

In a general pregentation of the hougehold production theory, conoumers in a typlcal hougehold combine their tine inputa with market goode (and gervices) to produce household non-market commodities, $\mathbf{z}_{y}, j=1, \ldots, n$. A vector of the houlehold commoditien directly enter the household utility function and the household maximizes the utility oubject to ita income and time constrainte, ofter named "full income" in the theory. Through this maximization problem we should be able to define a vartety of forme for the elasticties of demand for time allocation on various activitios as well as those for market goods. ${ }^{12}$

Here, for the purpose of our theoretical presentation in a comparative atatic analyalo, we asaume the following simple two non-market commoditiea model of the houshold:

$\mathrm{U}\left(\mathbf{z}_{1}, \mathbf{z}_{\mathrm{2}}\right)$,

where

$z_{1}=z_{1}\left(x_{1}, t_{21}\right)$,

and

$z_{2}=z_{2}\left(x_{2}, t_{13}, t_{m 2}\right)$

12 This general presentation, however, involves ungovernable calculation and 19 almost intractable, though not imposilble. For example, even in a very simple model such as only two household non-market commodities in the utility function, $1 . e ., U=U\left(z_{1}, z_{2}\right)$, where $z_{j}=z_{1}\left(x_{j}, t_{j}\right)$ for $j=1$ and 2 , it geema a little bit complicated that the elasticity of labor oupply with respect to wage rate is the proportion of total time epent at non-market

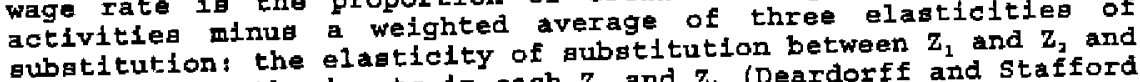
those between the inputa $1 n$ each $z_{1}$ and $z_{2}$ (Deardorff and stafford 1976, p. 679). 
where $U$ 1 1 utility funotion of the female, $f$, and male, $m$, membera of an average houehold; $x_{y}(j=1,2)$ is a vector of market good inputs; and $t_{1 y} 1 s$ the time input spent by person $i$ ( $1=f$, In) on production of $z_{j}$. In our epecification, the male specializes in production of $z_{2}$, but it certainly does not matter whether the male or the female in the household apecializes in production of $\mathrm{z}_{2}$. simply, we assume that there is a hougehold non-market commodity which requires only the time allocation of either one. Finally, we

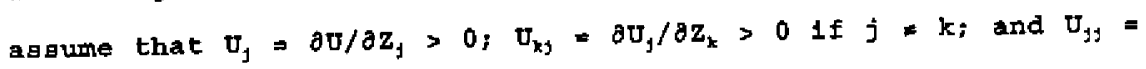
$\partial \mathrm{u}_{\mathrm{f}} / \partial \mathrm{z}_{\mathrm{y}}<0$.

For the household non-market commodities, the following fixedproportions production functions with inputs are assumed:

$x_{1}=a z_{1} ; x_{2}=b z_{\lambda} ; t_{c 1}=\alpha z_{1} ;$ and $t_{t 2}+t_{a 2} \& \beta z_{2}$,

where $a, b, \alpha$, and $\beta$ are poeltive coefficlenta.

The household maximizea the utility oubjeot to its full. Income, F, defined at:

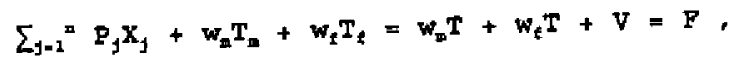

where $P_{f}$ is a vector of the unit prices of market gooda in $z_{y} ; w_{i}$ is the earnings per unit of time for person $1 ; T_{1}$ ia a vector of total time 1nputs spent by person 1 at the household non-market activities, $\theta . g, r, T_{2}=\sum_{y-1} t_{z y}, n=2, T$ is the total number of hours available such as 24 hourg $a$ day: ${ }^{13}$ and $v$ is non-labor household

13 Hence, $T_{1 \%}-T-T_{1}$ is the amount of time spent by pereon $i$ in the labor market. 
income.

The above maximization problem provides the following qualitative aigne of oln $t_{1 j} / \partial \ln w_{1},(1=f, m ;$ and $j=1,2)$ :

$$
\begin{aligned}
& \partial t_{t 1} / \partial w_{t}=-\left(t_{n}+t_{t 7}\right) \partial t_{n 1} / \partial F+\lambda\left(\pi_{2}^{a}-\pi_{2}^{t}\right) t-\left(\pi_{2}{ }^{2}-\pi_{2}{ }^{z}\right) \tau_{22 *} \\
& \left.+\left(\pi_{2}{ }^{2} U_{12 *}-\pi_{12}\right) U_{22 *}\right] D^{-1}<0 \text {; }
\end{aligned}
$$

and similarly,

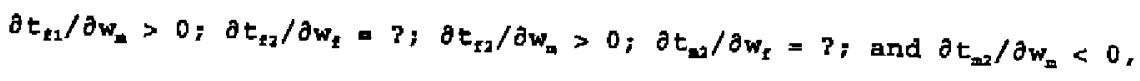
$\ldots \ldots(6)$

where $a t_{n 1} / \partial F$ is the full-income effect on $t_{t 1} ; \lambda$ is the marginal utility of full income; $\pi_{j}{ }^{1}$ is the $i-t h$ person's obadow price of $z_{j}$; $\mathrm{U}_{19 *}=\nabla_{19} / \alpha \beta_{;} U_{21 *}=\sigma_{29} / \theta^{2}$; and $\mathrm{D}$ is the determinant of the bordered Hegrian, defined ar:

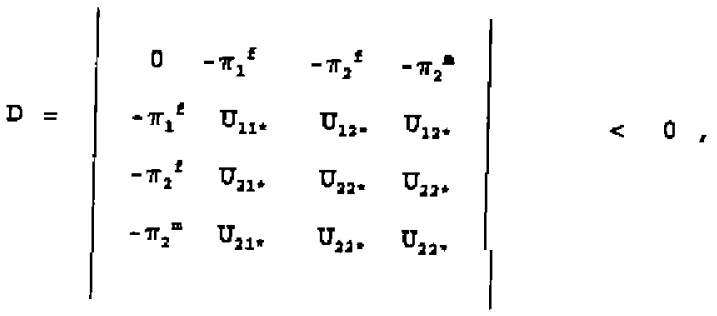

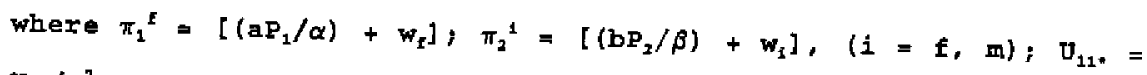
$\mathrm{U}_{21} / \alpha^{2} ; \mathrm{U}_{11^{*}}=\mathrm{U}_{21 * i}$ and we aEaume that $\sigma_{12 *} \mathrm{U}_{21 *}-\nabla_{11 *} \mathrm{D}_{22^{*}}<0$, (i.e., ${\sigma_{21}}^{2}$ $-U_{21} U_{22}<0$ ), for $D<0$.

From the above comparative atatic analysis, as female market wage rate rises, the female, only whose time input with market goode is required for the production of $z_{1}$, apende lear her time on $z_{1}$, but spends more as male market wage rate riseg. On the other hand, when the time of the female and that of the male are perfect 
substitutes such as $t_{t_{2}}+t_{\mathrm{m} 2}=\beta \mathrm{z}_{3}$, the qualitative signs of female wage effects on the female and male time spent on $z_{2}$ are ambiguous. In terms of their labor eupply to the market, the male wage effect on the female labor supply is negative, whlle it is poultive for the male labor aupply.14

To make the above hougehold production model emplrically operational, we take an approach of the household coot function in Deaton and Muelibauer (1980) and estimate a system of demand function, In which a typical 1 -th cost ghare function is defined at follows:

$s_{1}=a_{1}+\Sigma_{j} r_{1 y} \log p_{f}+b_{1} \log y$

where $S_{1}=p_{1} x_{1} /\left(\Sigma_{1-1}{ }^{2} P_{1} x_{1}+w_{n} T_{m}+w_{t} T_{f}\right)$, in which $p_{1}$ is the unit price of market good $x_{1} t^{15}$ and $y=\left(\Sigma_{y=1}{ }^{n} P_{y} X_{y}+w_{z} T_{m}+w_{f} T_{f}\right) / C P I$, in which CPI is the consumer price index.

The parameter reatrictions in equation (8) are $\Sigma_{1} a_{1}=1, \Sigma_{1} r_{1 y}$ $=\Sigma_{y} r_{1 j}=\Sigma_{i} b_{1}=0$ (the linearly homogenous condition) and $r_{1 j}=r_{1 j}$ (the sluteky symmetry condition). We apply this econometric model to the data on time allocations and comsumption expenditures of young and elderly households in Japan.

14 The wage effect on the male (or female) labor aupply to the market $1 \mathrm{~g}$ obtatned as followa: $\partial \mathrm{T}_{1 \mathrm{w}} / \partial \mathrm{w}_{1}=\partial \mathrm{T} / \partial \mathrm{w}_{1}-\partial \mathrm{T}_{1} / \partial \mathrm{w}_{1}$; and in the case of female labor aupply, we have $\partial \mathrm{T}_{\mathrm{f}} / \partial \mathrm{w}_{\mathrm{f}}=\partial \mathrm{T} / \partial \mathrm{w}_{\mathrm{f}}-\partial \mathrm{T}_{\mathrm{f}} / \partial \mathrm{w}_{\mathrm{f}}$ $=-\left(\partial t_{t 2} / \partial w_{t}+\partial t_{t 2} / \partial w_{t}\right)$.

25 For example, as one of the $s_{1}$ is concerned, the time eost ahare epent by the female on a particular household non-market activity, 1.e., $t_{f 1}$, is defined as $S_{j}=w_{t} t_{t j} /\left(\sum_{y=1}{ }^{n} P_{j} x_{j}+w_{n} T_{z}+w_{i} T_{t}\right)$. 
IV. Empirical Findinga

In the estimation of our ayatem of demand functions, we use pooled time aeries data for cities with prefectural government in 1976 , 1981 , and 1986 on the allocation of time for young males and Eemales both aged 25-39 as well as for elderly males aged 65 or more and those females aged 60 or more. ${ }^{16}$ we focus on their time allocations on sleep, child care, medical care, radio $t \mathrm{TV}$, and all other non-market time activitiea. These time data are collected from the Bagle Survey on Social Life. In the system, we also include five categories of household market goods and gervices consumption: food, housing, clothing, medical care, and all others." Among the total fifteen demand functions in the syatem, we delete the equation of the household consumption expenditure on "All Others" to avold the eingularity in the egtimation." Firet, in order to clarify whether the young (and elderly) houeeholds behave or not as the traditional consumer demand approach asaumes such that the household consumption expenditures are separable In their time allocations, we test for geparability in the hotisehold non-market time activities (Blackorby, Primont, and Russell 1977). We estimate the parameters of the syatem of

16 Each year has 47 prefectural observations.

17 Strictly tpeaking, in groupling numeroug household goods and Bervices coneumptions into different but appropriate categories, we have to verify whether oeparability condition is met or not for each 1 tem. This 1s, however, beyond our ocope in the present otudy. Therefore, wo follow the conventional classifications in Annual Report on the Family Income and Expenditure survey by statiotico Bureau, Management and Coordination Agency in Japan.

Io Each ohare equation in the system has two yearly dummies and seven regional dumies 1 n addition to a vector of the price varlables including the wage rates of males and females and income variable日. 
unconstrained demand functions and those of the aystem subject to the eeparability restrictions. From the chi-gquare distribution w1th 58 degreeg of freedom, 1.e., $x^{2}$ (d.f.=58), we cannot accept the separability restrictions at the significance level $\alpha=0.01$, a reported in Table II.1 Therefore, we consider that household deciaions on time allocation is Jointly determined with hougehold decisiong on consumption expenditures. To put it differently, the household labor aupply is not the result of a simple labor-leisure cholce, but the result of time activities in conjunction with household production. Hence, we support the findings of Barnett (1979) with our own Japanese data.

Tables III-(1) and (2) report the estimates of the wage and income elaticitiea of the time activities for the young households." In order to have a general view of the wage and income effects on their time activities, we begin with the egtimater of "All Households" of young males and females, as ahown under (A) in Table III-(1)."1

With regpect to the male wage effect, $W_{\text {min' }}$ on his time allocations, as his market wage rate riseg, a typical Japanese working male aged between 25 and 39 years old tends to increage hig hourg apent eleeping (1.e.. "Sleep" in Table) and working in the

1. For data on "Both (male and female) In the Labor Market" in Table II, we ube the data of working males of a given age group with those of working females of the same age group as a working couple. Similarly, we use data for those of nonly Male in the Labor Market" and "Neither in the Labor Market."

so See Bingwanger (1974) for the calculationg of the elasticitles and atandard errors.

21 Here, for the purpose of our preaent atudy we report only the empirical results of the hougehold allocation of time. Those on the consumption expenditures are avallable on request. 
labor market (1.e., "Labor supply" in Table) but to reduce his hourg apent on the other household non-market activities including "Medical Care"." The male wage effecte on female time activities are positive regarding the hourg of her aleeplng and ligtening to the radio and watching TV (1.e., "Radio $T^{n}$ in Table) but negative regarding all her other time activities including her labor supply. ${ }^{23}$ As regarda the effects of $W_{f m m 1 .}$ as the wage rate rises, the male enjoys more houre of aleeping, medical care, and ligtening to the radio and watching $T$, while the female worka more In the labor market. Another point concerning young households is that wage effecta on "child Care" for both males and females are negative, so we can conclude that they tend to choose to have less number of chlldren as their market opportunitieg improve. With regpect to income effects, as the household income riser, the young households apend more hours on household non-market time activitieg, 1.e., producing more household non-market comodities, but reduces their hours of work in the market.

Now we will highlight and discuss in a little more detall the important results concerning young working households, as reported In Tables III-(1) and (2). "Aa regards "Both in the Labor Market" under (B) in Table III-(1), the male (or female) wage effect on his

${ }^{27}$ Although not reported in Table III-(1), the eatimate of wage elasticity of "male'g all other non-market time activities" is negative, -0.746 .

23 The wage elaeticity on "female's all other non-market time activities" $1 \mathrm{~s}-0.18 \mathrm{a}$.

24 Since there are only a few qualitative differences in the empirical results between "Both in the Labor Market" as reported under (B) In Table III-(1) and "Only Male in the Labor Market" under (C) In Table III-(2), we focug only on those regulta of the former. 
(or her) aleeping is positive and statiotlcally signiflcant in contragt to the U.S. experience, where the effects are negative (B1ddle and Hamermesh 1990)..$^{35}$ The positive estimates for Japanese working males and fembles arg, however, not puzzling reault. Since our data on time allocation are weekly averager of time per day, a working couple may make up for a lack of weekday' gleeping hourg by eleepling more over the weekend. ${ }^{25}$

Also, as the market wage rates increase, both males and females increase thetr working hours: the eatimated labor oupply olasticity for males is 0.369 ; and that for females is $0.631 .{ }^{27}$ These valueg are comparable with those reported by the previous gtudiea (Shimada and Higuchl 1985 and Yamada, et al. 1987). The croas wage effects are negative for both males and females. That 1s, rige in the partner's market wage encouragea his (or her) withdrawal from the labor market. The estimated own wage and income elasticlties of female labor oupply are nearly twice as large a

27 The entimated own wage elagticity of sleeping for males is 0.153 , while the value 1s 0.147 for females: a ten-percent Iise in male wage rate increases his average sleeping time by about 7 minutes a day $[10 \times 0.00153 \times 463$ minutes (see, in Table $I-(1)$, that a typical male aged 25-39 "With a Job" sleeps 7:43, 1.e., 463 minuteg a day, in 1986)].

2I In Japanese cartoons, it is very common to have a character of a prime age working male who has no energy left with himeelf on a weekend due to his exceseive work during weekdays, e.g., daily overtime work till nearly midnight. He in the cartoon loves aleeplng at home on the weekend, although his wife and children are expecting that he would take his family out ouch ar a driving, ohopping, and so forth. They always wait a long timel This cynicien is not totally falae.

27 These labor supply elasticities are not directly obtained from the eetimated coefficiente in the oyotem of demand functions, since the share equations of male and female labor aupply are excluded from the ayatem by theory. The elasticities are almply a weighted average of the own wage elasticities of non-market activitieg. 
those for malea. This ia probably because the female has more alternatives in allocating her time than does her husband, since a married woman in Japan normally specializes in household production and ig consequently lege attached to the labor market than her вpoure.

Increaseg in hourg of sleeping and labor oupply for both males and females due to an increase in their market wage rates reduce their household non-market activities euch as rchild caren, "Medical Care", and "Radio \& TV". Thege findinge are congruent with thoge drawn in the caae of two-earner U.S. hougeholds by Rooreman and Rapteyn (1987). With respect to the "Child Care", the higher the opportunity cogt to raiae children for a typical working young couple the amaller will be the aize of family membera chosen by the household. Contrary to the negative wage effecte on child care, a ries in household income encourage them to epare more time for child care. That 18, an increage in household income ralese the number of children (and/or maybe the quality of children too) in the household.

With our study of the wage effect on the time allocation on medical care, the rosult is negative (as 1 s to be expected for both

"The total amount of parents' time, $T_{e}$, epent on children in a typłcal hourehold $i s t x \hat{s}$, where $t$ ia the average time opent on each child by the parenta and $N$ is the number of children in the hourehold. Then, aln $T_{c} / a I_{n}$ Income $=\partial \ln t / \partial \ln _{\mathrm{n}}$ Income $+\partial \mathrm{ln}_{\mathrm{N}} \mathrm{N} / \partial \mathrm{In}$ Income. From our empirical reault, we know aln $T_{a} / \partial \ln$ Income $>0$. Therefore, if $t$ 1s fixed, the number of children rises as the household income increasea, On the other hand, if $\mathrm{N}$ is fixed, the "quality (given the condition that the parents' time is superior to any other aubstitutes) " of child will increase as the income rises. In realty, a mixture of the positive income effects seem to be held on both $t$ and $\mathrm{N}$. 
working malea and females), but etatiatically ingignificant. ${ }^{29}$ A one-percent rloe in male wage rate reduces his time apent on medical care, e.g., walting at the hoepital, by about 3 percent (1.e., -3.009 for male "Medical Care" under $W_{\text {sul }}$ and -2.963 for female nMedical Caren under $\left.W_{t m i n}\right)$. Putting it differently, a typical working male reduce日 his time spent on hogpital vialta by about 6 minutes a week in regponge to a ten-percent increase in his wage rate [7 daya a week $\times 10 \times-0.03009 \times 3$ minutes epent on "Medical Caren by males "with a Job" in 1986 in Table I-(1)]. Although the value 1 tself to emall, this seems to be indicative of one of the reasons why prime age working males and females are rarely to be found wateing their turna in the busy lobbies of hospitals all day long.

Now we will digcuge the empirical reaults on elderly householde, a reported in Tables IV-(1) and (2). About the "All Householdg" under (A) in Table IV-(1), the $W_{\text {mel. }}$ effect is poiitive on male "labor supply" and a rise in the wage rate encourages his epoua to take more "sleep" and "Child Care" of, presumably, their grand-children. But, for the $W_{\text {tmele }}$ effect which $1 \mathrm{~s}$ positive on her market labor aupply, the male 19 not do helpful for caring grandchlldren. In other worda, when elderly people are not responsible for taking care of their grand-childxen, as their market economic opportunitieg rise, they geem not to retire early from the labor market.

The mogt atriking findinge for working elderly males, as shown

99 Thls wage effect on males 1 s negative and atatistically olgnificant for the case of "All Hougeholds" reported under (A) in Table III - (1) . 
under (B) in Table IV-(1) and under (C) in Table IV-(2), are that the wage effecta on their time epent on "sleep", "Child care", "Medical Care", and "Radio $\mathrm{TV}^{\mathrm{N}}$ are all negative and statiatically aignificant. ${ }^{30}$ The negative wage effect on "Medical Caren and the positive effect on "Labor Supply" for working elderly males clearly indicates that their condition of good health postpones their retirement from the labor market, in sharp contrast to the positive wage ffect on "Medical Care" for the "Nelther one in the Labor Market" household as reported under (D) in Table IV-(2). ${ }^{11}$ As for the $W_{\text {tmal }}$ effecta on her household non-market time activities, a general impresition to that the negative wage effects dominate, but that they are otatiatically much weaker in aignificance than with the male counterparts.

In aum, our emplrical findinga show that household decisions on the allocation of time 1a not independent of household dectalone on consumption expenditures. An increase in wage rateg otimulates the market labor supply for both young and elderly people, but generally reduces their non-market time activities. On the other hand, hougehold income has dominant positive effects on the time allocation on sleeping, child care, medical care, and listening to the radio and watching TV.

30 These qualitative resulte are similar to those for working young males except for the effect on "Sleep", but the otatigtical resulte for working young males are much weaker than those with working elderly males.

31 Ag often done in the literature of labor economica, A wage equation for non-participanta in the labor narket should be estimated in an appropriate manner. Since we are not successful in collecting the relevant variables for the equation, we instead use the induatry average wage rated for the non-participanta. Therefore, our resulta for them are only suggestive. 
v. Conclusiong and Implications

In this atudy, by using the pooled time serieg data in 1976, 1981, and 1986, we analyze the allocation of time of young (aged 25-39) and elderly (aged 65 or more) househoIds in Japan. We estimate a syotem of demand functions, in which the equations of household non-market time activitiea are almultaneourly eatimated with thoge of household consumption expenditurea.

Among the noteworthy findinge derived from our data, firat of all. In our test for separability in the houbehold time allocation, we cannot accept the aeparabllity restrictions. Hence, as has already been suggested by some U.S. data, our Japanese data show that hougehold non-market time allocations (coneguently, its market labor aupply) are not reparable from congumption expenditurea.

Secondly, an increase in the market wage rates for both young and elderly households reduces their time spent on the hougehold non-market activities such as child care, medical care, and listening to the radio and watching TV. We consider one reason why young working couples have amaller familles in recent years to be bound up with the improvements in their economic opportunities in the labor market. Since fewer children are born and fewer working people are now supporting currently retired people than in the past, and aince the tre trends will continue in the near future, ralaing the retirement age recomended by the Japanese government would encourage people to work longer and thus would reduce the ratio of retired to working age people.

Thirdly, as hypothesized, the high opportunfty costs of waiting at the hoapital clearly discourage working people from 
visiting the hospital. Requiring firme to have their own clinics and encouraging hospitals to make appointments for patiente would reduce watting time.

As a concluding remark, our atudy shows that the household production theory illuminatea the behavior of households in the allocation of time and consumption expenditures. The reaulta of our empirical model based on the theory show not a few similarities between the forme of hougehold behaviox in different cultures, e.g., the U.S. and Japan. 
REPERENCES

Becker, G. S. "A Theory of the Allocation of Time." Economic Journal 75 (September 1965): $493-517$.

Barnett, William A. "The Joint Allocation of Leisure and Goode Expenditure." Econometrtca 47 (May 1979): $539-563$.

Barten, Anton P. "The Syotems of Conetmer Demand Functions

Approach: A Review." In Erontiers of Quantitative Economice,

Vol. IIIA, edited by Michael D. Intriligator. Ameterdam:

North-Folland Publighing Company, 1977.

Biddle, Jeff E. and Hamermesh, Daniel S. "Sleep and the Allocation of Time." Journal of Rolitical Economy 98 (October 1990): $922-943$.

Binswanger, Hang P. "The Meaburement of Technical Change Biases with Many Factore of Production." American Economlc Review 64 (December 1974) $\div$ 964-976.

Blackorby, Charles, primont, Daniel, and Ruseet1, R. Robert. "On Teeting Separability Regtrlctiong With Flexible Functional Forms," Journal of Econometr1e日 5 (March 1977): 195-209. Blundell, Richard. MConaumer Behaviour: Theory and Empirical Evidence - A Survey " Economic Journal 98 (March 1988): $16-65$.

Brown, A. and Deaton, A. "Models of Consumer Behaviour: A Survey." Economic Journal B2 (December 1972) : 1145-1236.

Deardorff, Alan v, and stafford, Frank P. "Compenation of Cooperating Factork." Econometr1ca 44 (JulY 1976): 671-684. Deaton, Angus $S$. "Demand Analyais." In Handbook of Econometrics, Vol. III, edited by Zvi Griliches and Michael D. Intriligator. Amaterdam: North-Holland, 1986. 
, and Muellbauer, John. "An Almost Ideal Demand Syatem."

American Economic Review 70 (June 1980) : $312-326$.

- Economice and Consumer Behavior. Cambridge: Cambridge

University Prese, 1983.

Diewert, w. E. "Applications of Duality Theory." In Frontiers of Quantitative Economice, Vol. 2, edited by Michael D.

Intriligator and David A. Rendrick. Amsterdam: North-Holland, 1974.

Edwards, Iinda N. "Equal Employment Opportunity in Japan: A View from the Wegt." Indugtrial and Labor Relations Review 41 (January 1988): 240-250.

Juster, F. Thomas, and Stafford, Frank P. "The Allocation of T1me: Empirical Findings, Behavioral Models, and problems of Measurement." Journal of Economic Literature 29 (June 1991): $471-522$.

Kooreman, Peter and Kapteyn, Arie. "A Díaggregated Analyoie of the Allocation of Time within the Hourehold." Journal of Political Economy 95 (ApFil 1987) : $223-249$.

Lau, Lawrence J. "Complete Syatems of Conbumer Demand Functions through Duality." In Frontiera of Quantitative Economics, vol. IIIA, edited by Michael D. Intriligator. Amsterdan: NorthHolland, 1977 .

Shimada, Haruo, and Higuchl, Yooh1o. "An Analyeia of Trenda in Female Labor Force Farticipation in Japan." Journal of Labor Economica 3 (January 1985); 9355-E374. 
Yamada, Tadash1, Yamada, Tetsuji, and Chaloupka, Frank. "Uling Aggregate Data to Eatimate the Part-Time and Full-Time work Behavior of Japanese Women." Journal of Human Resources 22 (Fal1 1987): 574-583. 
TABLE $I-(I)$

Hours and Minutes per Day opent on Activities

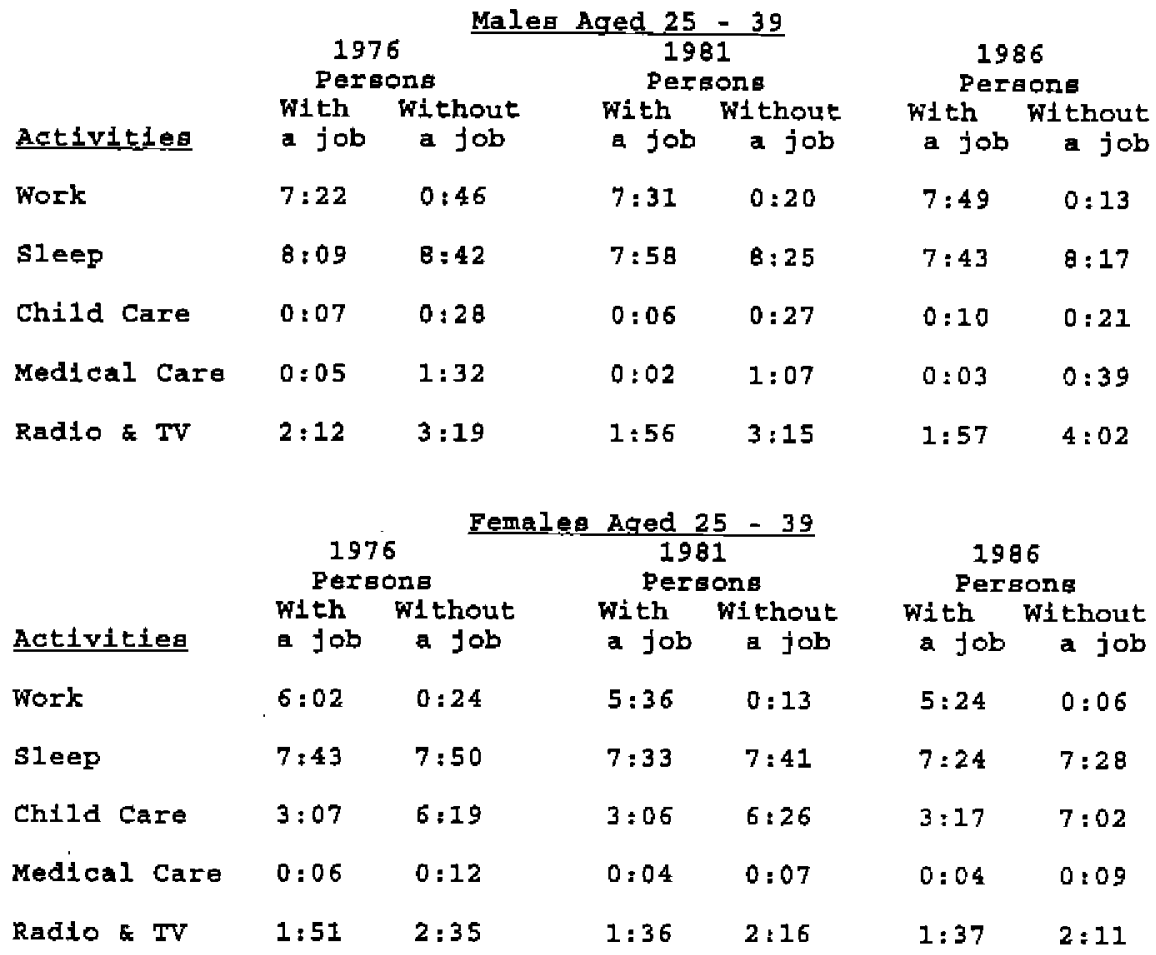

Note: Valuea in Table should read in Fours:Minutea, e.g., 7:22=7 hourg and 22 minuter a day. Medical care implies medical examination and treatment at clinicg and hospitali. Child Care includes House keeping, and Radio $\mathrm{TV}$ includes time spent on reading newspapers and magazines.

Sources: Bureau of statistics, office of the Prime Minister in Japan, Basic Survey on Social ilfe - Whole Japan : Time Spent on Activitien, 1976 (Pp. 18-23), 1981 (pP. 26-43), and 1986 (pp. 2643). 
TABLE I- (2)

Hours and Minutes per Day epent on Activities

\begin{tabular}{|c|c|c|c|c|c|c|}
\hline \multirow[b]{2}{*}{ Activitieg } & \multicolumn{2}{|c|}{$\begin{array}{c}1976 \\
\text { Persong }\end{array}$} & \multicolumn{2}{|c|}{$\begin{array}{c}1981 \\
\text { Pergons }\end{array}$} & \multicolumn{2}{|c|}{$\begin{array}{c}1986 \\
\text { Pereong }\end{array}$} \\
\hline & $\begin{array}{l}\text { With } \\
\text { a job }\end{array}$ & $\begin{array}{l}\text { Without } \\
\text { a job }\end{array}$ & $\begin{array}{l}\text { w1th } \\
\text { a job }\end{array}$ & $\begin{array}{l}\text { Without } \\
\text { a Job }\end{array}$ & $\begin{array}{l}\text { with } \\
\text { a job }\end{array}$ & $\begin{array}{l}\text { W1 thout } \\
\text { a job }\end{array}$ \\
\hline Work & $5: 36$ & $0: 39$ & $6: 50$ & $0: 23$ & $5: 33$ & $0: 12$ \\
\hline sleap & $8: 50$ & $9: 34$ & $8: 32$ & $9: 34$ & $8: 29$ & $9: 11$ \\
\hline Child Care & $0: 10$ & $0: 23$ & $0: 11$ & $0 \div 29$ & $0: 15$ & $0: 37$ \\
\hline Nedical Care & $0: 17$ & $1: 18$ & $0: 11$ & $0: 47$ & $0: 11$ & $0: 44$ \\
\hline Radio \& TV & $2: 54$ & $4: 07$ & $2: 43$ & $4: 22$ & $2: 55$ & $4: 30$ \\
\hline & $\begin{array}{l}197 \\
\text { Pere }\end{array}$ & $\begin{array}{l}\text { Femele } \\
\text { ons }\end{array}$ & $\begin{array}{r}\text { ged } 60 \\
19 \\
\text { per }\end{array}$ & and Over & $\begin{array}{r}198 \\
\text { Pexs }\end{array}$ & $\begin{array}{l}36 \\
30 \pi s\end{array}$ \\
\hline Activitien & a Job & a job & a Job & $\begin{array}{l}\text { Mithout } \\
\text { a Job }\end{array}$ & a Job & $\begin{array}{r}\text { Without } \\
\text { a Job }\end{array}$ \\
\hline Work & $4: 49$ & $0: 40$ & $5: 13$ & $0: 21$ & $4: 36$ & $0: 10$ \\
\hline sleep & $8: 26$ & $8: 55$ & $8: 08$ & $8: 56$ & $8: 13$ & $8: 52$ \\
\hline Child Care & $2: 1,5$ & $3: 09$ & $2: 17$ & $2: 58$ & $2: 19$ & $2: 45$ \\
\hline Medical Care & $0: 14$ & $0: 39$ & $0: 08$ & $0: 31$ & $0: 14$ & $0: 36$ \\
\hline kadio \& TV & $2 \div 31$ & $3: 25$ & $2: 14$ & $3: 32$ & $2 \div 25$ & $3: 35$ \\
\hline
\end{tabular}

Note: Values in Table ahould read in Hours:Minuteg, e.g., 5:36=5 hours and 36 minutes a day. Medical care implies medical examination and treatment at clinics and hospltalo. Child Care includes House Keeping, and Radio $\bar{x}$ TV includes time spent on reading newrpapers and magazines.

Sources: Bureau of Statiatica, offlce of the Prime Minister in Japan, Baatc Surver on Soctal Life - Whole Japan : Time Spent on Activitien, 1976 (PP, 18-23), 1981 (pp. 26-43), and 1986 (PP. 2643). 
TABLE II

Test for Separability in the Household Time Allocation

A Household of Male and Female aged 25-39

$$
\begin{aligned}
& \text { Log of Likelihood } \\
& \text { Function }
\end{aligned}
$$

Incongtrained

A

All Households

Both in the

Labor Market

only Male in the

Labor Market

$$
9467.58
$$

9564.35

9673.96
Iog likelihood Ratio

$2(A-B)$

$B$

$$
9418.93
$$

$97.30^{\circ}$

9502.46

$123.78^{*}$

9613.69

\section{A Household of Male aged 65 and over and Female aged 60 and over}

\section{Log of Iikelihood Function}
Unconetrained Constrained
A
$B$

All Hougeholda

\section{Both in the}

Labor Market

only Male in the

Labor Market

Neither one in

the Labor Market
8358.94

8282.50

7730.90

8103.18

8130.40
Log likelihood Ratio

$2\langle A-B\rangle$

$152.88^{*}$

$251.20^{\circ}$

$144.20^{\circ}$

$145.66^{\circ}$

a: vignificant at the $1 \%$ level.

Note: The degreed of freedom are $\chi^{2}(58)$. 
TABLE III - (1)

Eatimates of Wage and Income Elasticlties of the Allocation of Time A Houeahold of Male and Female aged 25-39

\section{All Fougeholdg}

\begin{tabular}{|c|c|c|c|c|c|c|c|}
\hline $\begin{array}{l}\text { Allocatio } \\
\text { of time }\end{array}$ & on Wit $\begin{array}{c}\text { Wit } \\
\text { Wmale }\end{array}$ & $\begin{array}{l}\text { Respec } \\
\text { Wfemale }\end{array}$ & $\begin{array}{l}\text { to } \\
\text { Income }\end{array}$ & $\begin{array}{l}\text { Allocati } \\
\text { of time }\end{array}$ & Lon Wit & $\begin{array}{l}\text { th Reapec } \\
\text { Wfemale }\end{array}$ & $\begin{array}{l}\text { et to } \\
\text { Income }\end{array}$ \\
\hline \multicolumn{4}{|l|}{ Male } & \multicolumn{4}{|l|}{ Female } \\
\hline sleep & $\begin{array}{r}0.172 \\
(0.040)\end{array}$ & $\begin{array}{c}0.353^{\circ} \\
(0.029)\end{array}$ & $\begin{array}{l}0.002 \\
(0.059)\end{array}$ & sleep & $\begin{array}{c}0.073 \\
(0.159)\end{array}$ & $\begin{array}{c}0.135 \\
(0.116)\end{array}$ & $\begin{array}{c}0.220 \\
(0.234)\end{array}$ \\
\hline $\begin{array}{c}\text { Child } \\
\text { Care }\end{array}$ & $\begin{array}{l}-1.314 \\
(1.146)\end{array}$ & $\begin{array}{l}-2.081^{b} \\
(0.838)\end{array}$ & $\begin{array}{r}3.742^{b} \\
(1.686)\end{array}$ & $\begin{array}{r}\text { Child } \\
\text { Care }\end{array}$ & $\begin{array}{c}-0.003 \\
(0.246)\end{array}$ & $\begin{array}{r}-1.080^{*} \\
(0.179)\end{array}$ & $\begin{array}{l}2.015^{\prime} \\
(0.361)\end{array}$ \\
\hline $\begin{array}{c}\text { Medical } \\
\text { Caro }\end{array}$ & $\begin{array}{l}-4.471^{\circ} \\
(2.649)\end{array}$ & $\begin{array}{c}0.872 \\
(1.937)\end{array}$ & $\begin{array}{c}2.787 \\
(3.898)\end{array}$ & $\begin{array}{l}\text { Medical } \\
\text { Care }\end{array}$ & $\begin{array}{c}-7.041 \\
(1.886)\end{array}$ & $\begin{array}{l}-1.154 \\
(1.379)\end{array}$ & $\begin{array}{r}7.780^{\circ} \\
(2.775)\end{array}$ \\
\hline $\begin{array}{l}\text { Radio } \\
\text { \& } T V\end{array}$ & $\begin{array}{l}-0.038 \\
(0.251)\end{array}$ & $\begin{array}{c}0.196 \\
(0.184)\end{array}$ & $\begin{array}{c}0.406 \\
(0.369)\end{array}$ & $\begin{array}{l}\text { Radio } \\
\& \mathrm{TV}\end{array}$ & $\begin{array}{r}0+182 \\
(0.298)\end{array}$ & $\begin{array}{l}-0.557^{b} \\
(0.218)^{2}\end{array}$ & $\begin{array}{l}1.136^{4} \\
(0.439)\end{array}$ \\
\hline $\begin{array}{l}\text { Labor } \\
\text { supply }\end{array}$ & $\begin{array}{r}0.509^{*} \\
(0.010)\end{array}$ & $\begin{array}{c}-0.244^{\circ} \\
(0.005)\end{array}$ & $\begin{array}{c}-1.602^{n} \\
(0.021)\end{array}$ & $\begin{array}{l}\text { Labor } \\
\text { Supply }\end{array}$ & $\begin{array}{l}-0.266 \\
(0.260)\end{array}$ & $\begin{array}{c}1.991^{\circ} \\
(0.139)\end{array}$ & $\begin{array}{c}-6.393^{*} \\
(0.564)\end{array}$ \\
\hline
\end{tabular}

af significant at the $1 \%$ lovel.

$b$ : aignificant at the $5 \%$ level.

$c$ : Bignificant at the $10 \%$ level.

Note: The own wage elaaticity 1 o defined as $\in 1,1=\left(x_{11} / a_{1}\right)+g_{1}-1$; the

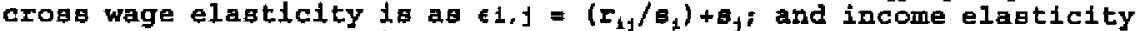
is as $\eta_{1.10 t a r}=\left(b_{1} \operatorname{lncos} / a_{1}\right)+1$. All the elasticities are evaluated at the sample means. $S_{1}$ is the total expenditure ehare of 1 -th input. The atandard errors are in parentheses. 
TABLE III-(2)

Eatimates of Wage and Income Elagtlolties of the Allocation of Time

\title{
A Household of Male and Female aged 25-39
}

\section{Both in the Labor Market}

\begin{tabular}{|c|c|c|c|c|c|c|c|}
\hline $\begin{array}{l}\text { Allocati } \\
\text { of time }\end{array}$ & on Wit & $\begin{array}{l}\text { h Reapec } \\
\text { Wfemale }\end{array}$ & $\begin{array}{l}\text { to } \\
\text { Income }\end{array}$ & $\begin{array}{l}\text { Alloceti } \\
\text { of time }\end{array}$ & $\begin{array}{c}\text { on Wi } \\
\text { Wmale }\end{array}$ & $\begin{array}{l}\text { h Respec } \\
\text { wfemale }\end{array}$ & $\begin{array}{l}\text { et to } \\
\text { Income }\end{array}$ \\
\hline Malo & & & & Female & & & \\
\hline sleep & $\begin{array}{r}0.153^{*} \\
(0.039)\end{array}$ & $\begin{array}{c}0.293^{2} \\
(0.028)\end{array}$ & $\begin{array}{l}0.070 \\
(0.058)\end{array}$ & sleep & $\begin{array}{r}0.137^{5} \\
(0.056)\end{array}$ & $\begin{array}{c}0.147^{\circ} \\
(0.040)\end{array}$ & $\begin{array}{l}0.002 \\
(0.083)\end{array}$ \\
\hline $\begin{array}{r}\text { Child } \\
\text { Care }\end{array}$ & $\begin{array}{l}-1.362 \\
(1.080)\end{array}$ & $\begin{array}{c}-2.008^{\circ} \\
(0.772)\end{array}$ & $\begin{array}{r}3.684^{3} \\
(1.603)\end{array}$ & $\begin{array}{l}\text { Child } \\
\text { Care }\end{array}$ & $\begin{array}{c}-0.277 \\
(0.323)\end{array}$ & $\begin{array}{l}-1.217^{*} \\
(0.231)\end{array}$ & $\begin{array}{c}1.992^{\circ} \\
(0.479)\end{array}$ \\
\hline $\begin{array}{c}\text { Medical } \\
\text { Care }\end{array}$ & $\begin{array}{l}-3.009 \\
(2.554)\end{array}$ & $\begin{array}{l}-0.709 \\
(1.827)\end{array}$ & $\begin{array}{c}2.218 \\
(3.792)\end{array}$ & $\begin{array}{l}\text { Medical } \\
\text { Care }\end{array}$ & $\begin{array}{c}-7.417^{\mathrm{b}} \\
(3.109)\end{array}$ & $\begin{array}{l}-2.963 \\
(2.224)\end{array}$ & $\begin{array}{l}10.165^{b} \\
(4.615)\end{array}$ \\
\hline $\begin{array}{l}\text { Radio } \\
\text { E TV }\end{array}$ & $\begin{array}{c}-0.030 \\
(0.249)\end{array}$ & $\begin{array}{c}0.267 \\
(0.178)\end{array}$ & $\begin{array}{c}0.277 \\
(0.370)\end{array}$ & $\begin{array}{l}\text { Radio } \\
\text { E TV }\end{array}$ & $\begin{array}{c}0.174 \\
(0.319)\end{array}$ & $\begin{array}{c}-0.330 \\
(0.228)\end{array}$ & $\begin{array}{r}0.973^{b} \\
(0.474)\end{array}$ \\
\hline $\begin{array}{l}\text { Labor } \\
\text { Supply }\end{array}$ & $\begin{array}{r}0.369^{\circ} \\
(0.009)\end{array}$ & $\begin{array}{r}-0.218^{*} \\
(0.004)\end{array}$ & $\begin{array}{c}-1.467^{\circ} \\
(0.019)\end{array}$ & $\begin{array}{l}\text { Labor } \\
\text { Supply }\end{array}$ & $\begin{array}{c}-0.039 \\
(0.042)\end{array}$ & $\begin{array}{c}0.631 \\
(0.021)\end{array}$ & $\begin{array}{l}-2.606^{2} \\
(0.092)\end{array}$ \\
\hline
\end{tabular}

\begin{abstract}
a: Bignificant at the 18 level.
b: olgnificant at the 5 t level.

c) olgniflcant at the $10 \%$ level.
\end{abstract}

Note: The own wage elasticity $1_{8}$ defined as $\epsilon i_{1}:=\left(x_{11} / s_{1}\right)+s_{1}-1$, the

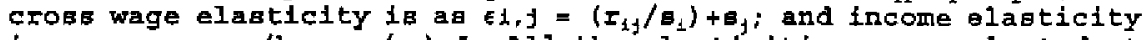
is as $\eta_{\text {1.1neos }}=\left(\mathrm{b}_{\mathrm{f} .1 \mathrm{neose}} / \mathrm{s}_{1}\right)+1$. All the elasticleies are evaluated at the sample means. $S_{1}$ is the total expenditure ghare of $1-t h$ input. The atandard arrorg are in parentheaes. 
TABLE III- (3)

Estimateg of Wage and Income Elastictties of the Allocation of Time A Hougehold of Male and Female aged 25-39

\section{Only Male in the Labor Market}

\begin{tabular}{|c|c|c|c|c|c|c|c|}
\hline $\begin{array}{l}\text { Allocati } \\
\text { of time }\end{array}$ & $\begin{array}{c}\text { Wit } \\
\text { Wmale }\end{array}$ & $\begin{array}{l}\text { h Reopect } \\
\text { wfemale }\end{array}$ & $\begin{array}{l}\text { to } \\
\text { Income }\end{array}$ & $\begin{array}{l}\text { Allocati } \\
\text { of time }\end{array}$ & on & $\begin{array}{l}\text { th Respec } \\
\text { Wfemale }\end{array}$ & $\begin{array}{l}\text { ct to } \\
\text { Income }\end{array}$ \\
\hline \multicolumn{4}{|l|}{ Male } & \multicolumn{4}{|l|}{ Female } \\
\hline sleep & $\begin{array}{r}0.154= \\
(0.043)\end{array}$ & $\begin{array}{c}0.363^{2} \\
(0.038)\end{array}$ & $\begin{array}{l}0.032 \\
(0.078)\end{array}$ & sleep & $\begin{array}{c}0.105 \\
(0.067)\end{array}$ & $\begin{array}{c}0.161 \\
(0.059)\end{array}$ & $\begin{array}{c}0.027 \\
(0.121)\end{array}$ \\
\hline $\begin{array}{c}\text { Child } \\
\text { Care }\end{array}$ & $\begin{array}{l}-2.052^{\circ} \\
(1.170)\end{array}$ & $\begin{array}{r}-3.074^{4} \\
(1.028)\end{array}$ & $\begin{array}{l}5.751^{*} \\
(2.108)\end{array}$ & $\begin{array}{c}\text { Chfld } \\
\text { Care }\end{array}$ & $\begin{array}{c}0.458^{\circ} \\
(0.256)\end{array}$ & $\begin{array}{l}-0.332 \\
(0.225)\end{array}$ & $\begin{array}{c}0.495 \\
(0.461)\end{array}$ \\
\hline $\begin{array}{c}\text { Medical } \\
\text { Care }\end{array}$ & $\begin{array}{l}-2.033 \\
(2.797)\end{array}$ & $\begin{array}{c}-0.881 \\
(2.458)\end{array}$ & $\begin{array}{c}2.300 \\
(5.039)\end{array}$ & $\begin{array}{l}\text { Medical } \\
\text { Care }\end{array}$ & $\begin{array}{c}-5.925^{b} \\
(2.403)\end{array}$ & $\begin{array}{c}-0.348 \\
(2.112)\end{array}$ & $\begin{array}{r}5.626 \\
(4.329)\end{array}$ \\
\hline $\begin{array}{r}\text { Radio } \\
\text { TV }\end{array}$ & $\begin{array}{l}-0.176 \\
(0.271)\end{array}$ & $\begin{array}{c}0.109 \\
(0.238)\end{array}$ & $\begin{array}{c}0.742 \\
(0.488)\end{array}$ & $\begin{array}{l}\text { Radio } \\
\text { TV }\end{array}$ & $\begin{array}{c}0.964 \\
(0.363)\end{array}$ & $\begin{array}{r}0.347 \\
(0.319)\end{array}$ & $\begin{array}{c}-1.006 \\
(0.654)\end{array}$ \\
\hline $\begin{array}{l}\text { Labor } \\
\text { Supply }\end{array}$ & $\begin{array}{r}0.497^{\circ} \\
(0.011)\end{array}$ & $\begin{array}{c}-0.053^{\circ} \\
(0.008)\end{array}$ & $\begin{array}{c}-1.910^{4} \\
(0.034)\end{array}$ & & & & \\
\hline
\end{tabular}

a: eignificant at the $1 \%$ level. b: eignificant at the 5o level. a: eignificant at the 10 s level.

Note: The own wage elasticity 1e defined as $\epsilon_{1,1}=\left(\tau_{11} / a_{1}\right)+s_{1}-1$; the

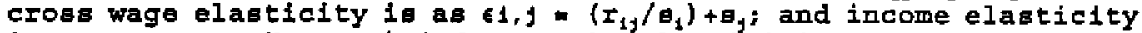

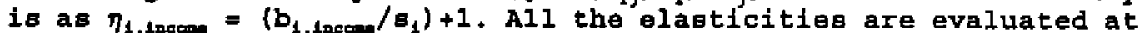
the aample means. $S_{1}$ is the total expenditure ghare of $i-t h$ input. The otandard errorg are in parentheses. 
TABLE IV- (1)

Estimates of Wage and Income Elagticitieg of the Allocation of Time A Hourehold of Male aged 65 and over and Female aged 50 and over

\section{All Hougeholde}

Allocation with Regpect to of time Wnale Wfemale Income

Male

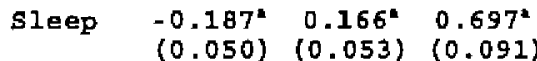

$$
\begin{aligned}
& \begin{array}{cccc}
\text { Child } & -1.502^{\circ} & -0.262 & 1.883^{b} \\
\text { Care } & (0.520) & (0.544) & (0.936)
\end{array} \\
& \text { Medical }-0.203 \quad-0.357 \quad 1.431 \\
& \text { Care }(0.767)(0.803) \quad(1.382) \\
& \begin{array}{cccc}
\text { Radio } & -0.448^{*} & -0.023 & 1.101 * \\
\text { E TV } & (0.142) & (0.148) & (0.255)
\end{array} \\
& \text { Labor } \quad 1.923^{*}-0.587^{*}-6.067^{*} \\
& \text { Supply }(0.057)(0.044)(0.194)
\end{aligned}
$$

\footnotetext{
a: Bignificant at the 1 is level.

b: signiflcant at the $5 \%$ level.

c: algnificant at the 10 \% level.
}

Allocation With Respect to of time Wmale wfemale Inoome

\section{Female}

$$
\begin{array}{cccc}
\text { Sleep } & 0.199^{\circ} & -0.005 & 0.473^{\circ} \\
& (0.036) & (0.038) & (0.065) \\
\text { Ch1ld } & 0.227 & -0.130 & 0.367 \\
\text { Care } & (0.153) & (0.160) & (0.276) \\
\text { Medical } & -0.553 & -0.596 & 2.230^{\circ} \\
\text { Care } & (0.523) & (0.547) & (0.941) \\
\text { Radio } & -0.045 & -0.296^{\circ} & 0.968^{\circ} \\
\text { \& TV } & (0.114) & (0.119) & (0.205) \\
& & & \\
\text { Labor } & -2.424^{\circ} & 0.930^{\circ} & -8.441^{\circ} \\
\text { Supply } & (0.159) & (0.174) & (0.517)
\end{array}
$$

Note: The ow wage elagticity is defined ag $\epsilon 1,1=\left\langle r_{i i} / a_{1}\right)+B_{1}-1$; the croas wage elagticity is as $\epsilon_{1} f=\left(r_{1 j} / B_{1}\right)+E_{j}$; and income elasticity

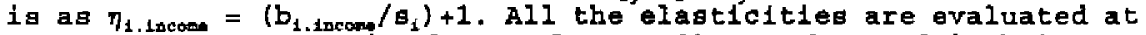
the aample means. $S_{1}$ is the total expenditure share of $i-t h$ input. The standard exrors are in parentheses. 
TABLE IV- (2)

Egtimates of Wage and Income Elagticitieg of the Allocation of Time

A Eougehold of Male aged 65 and over and Female aged 60 and over

\section{Both in the Labor Market}

Allocation With Respect to of time Wrale wfemale Income

Male

$$
\begin{array}{cccc}
\text { sleep } & -0.151^{\circ} & 0.204^{\circ} & 0.616^{\circ} \\
& (0.047) & (0.049) & (0.084) \\
\text { Child } & -1.934^{b} & -0.767 & 2.629^{\circ} \\
\text { Care } & (0.826) & (0.864) & (1.489)
\end{array}
$$$$
\begin{array}{cccc}
\text { Medical } & -1.883^{\mathrm{c}} & -1.491 & 3.359^{\mathrm{c}} \\
\text { Care } & (1.089) & (1.139) & (1.963)
\end{array}
$$$$
\begin{array}{cccc}
\text { Radio } & -0.507^{*} & 0.074 & 0.814^{*} \\
\text { \& TV } & (0.139) & (0.146) & (0.251)
\end{array}
$$$$
\begin{array}{lccc}
\text { Labor } & 0.863^{*} & -0.259^{*} & -2.623^{*} \\
\text { Supply } & (0.011) & (0.012) & (0.034)
\end{array}
$$

Allocation With Reapect to * of time Wmale Wfemale Income

Female

$$
\begin{array}{cccc}
\text { Sleep } & 0.238^{\circ} & 0.085^{\mathrm{b}} & 0.376^{\circ} \\
& (0.041) & (0.043) & (0.074) \\
\text { Chlld } & -0.066 & -0.532^{\mathrm{b}} & 1.001^{\circ} \\
\text { Care } & (0.201) & (0.210) & (0.362) \\
\text { Medical } & -1.714 & 0.995 & -0.836 \\
\text { Care } & (1.660) & (1.736) & (2.993) \\
\text { Radio } & -0.381^{b} & -0.717^{\circ} & 1.612^{\circ} \\
\text { E TV } & (0.177) & (0.185) & (0.319) \\
\text { Labor } & -0.240^{\circ} & 0.516^{\circ} & -2.816^{\circ} \\
\text { Supply } & (0.024) & (0.026) & (0.078)
\end{array}
$$

a: ignificant at the $1 \%$ level.
b: Bignificant at the $5 \%$ level.
ct Bignificant at the $10 \%$ level.

Note: The own wage elastictty le defined ag $E_{1} i=\left(r_{11} / B_{1}\right)+B_{1}-1$, the cross wage elasticity í a $\epsilon_{t, j}=\left(x_{1 j} / a_{1}\right)+B_{j}$; and income elasticity

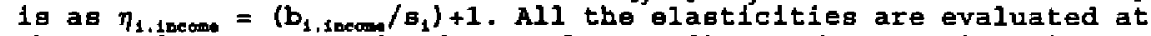
the eample means. $S_{1}$ le the total expenditure ehare of 1 -th input. The standard errors are in parentheses. 
TABLE IV- (3)

Entimates of Wage and Income Elasticities of the Allocation of Time A Hougehold of Male aged 65 and over and Female aged 60 and over

\title{
Only Male in the Labor Market
}

\begin{tabular}{|c|c|c|c|c|c|c|c|}
\hline $\begin{array}{l}\text {-Allocatio } \\
\text { of time }\end{array}$ & on wit $\begin{array}{c}\text { Wite } \\
\text { Wmale }\end{array}$ & $\begin{array}{l}\text { h Respec } \\
\text { Wfemale }\end{array}$ & $\begin{array}{l}\text { to } \\
\text { Income }\end{array}$ & $\begin{array}{l}\text { Allocati } \\
\text { of time }\end{array}$ & on Wit & $\begin{array}{l}\text { h Respec } \\
\text { Wfemale }\end{array}$ & $\begin{array}{l}\text { te to } \\
\text { Income }\end{array}$ \\
\hline \multicolumn{4}{|l|}{ Male } & \multicolumn{4}{|l|}{ Fema Ie } \\
\hline sleep & $\begin{array}{c}-0.259^{4} \\
(0.048)\end{array}$ & $\begin{array}{c}0.097 \\
(0.060)\end{array}$ & $\begin{array}{c}0.874^{2} \\
(0.097)\end{array}$ & sleep & $\begin{array}{c}0.257 \\
(0.043)\end{array}$ & $\begin{array}{c}0.057 \\
(0.053)\end{array}$ & $\begin{array}{r}0.291 \\
(0.086)\end{array}$ \\
\hline $\begin{array}{c}\text { Child } \\
\text { Care }\end{array}$ & $\begin{array}{l}-1.990^{\circ} \\
(0.873)\end{array}$ & $\begin{array}{l}-1.001 \\
(1.087)\end{array}$ & $\begin{array}{r}2.952^{\circ} \\
(1.764)\end{array}$ & $\begin{array}{l}\text { Child } \\
\text { Cara }\end{array}$ & $\begin{array}{c}0.301^{b} \\
(0.152)\end{array}$ & $\begin{array}{l}-0.015 \\
(0.190)\end{array}$ & $\begin{array}{c}0.173 \\
(0.308)\end{array}$ \\
\hline $\begin{array}{l}\text { Medical } \\
\text { Care }\end{array}$ & $\begin{array}{c}-1.960^{c} \\
(1.154)\end{array}$ & $\begin{array}{c}-1.835 \\
(1.437)\end{array}$ & $\begin{array}{c}3.805 \\
(2.333)\end{array}$ & $\begin{array}{l}\text { Medical } \\
\text { Care }\end{array}$ & $\begin{array}{c}-0.514 \\
(0.475)\end{array}$ & $\begin{array}{l}-0.970 \\
(0.591)\end{array}$ & $\begin{array}{r}2.7874 \\
(0.960)\end{array}$ \\
\hline $\begin{array}{r}\text { Radio } \\
\& T V\end{array}$ & $\begin{array}{l}-0.698^{4} \\
(0.144)\end{array}$ & $\begin{array}{c}-0.188 \\
(0.179)\end{array}$ & $\begin{array}{c}1.316^{*} \\
(0.290)\end{array}$ & $\begin{array}{l}\text { Radio } \\
\text { TV }\end{array}$ & $\begin{array}{c}0.140 \\
(0.104)\end{array}$ & $\begin{array}{l}-0.069 \\
(0.129)\end{array}$ & $\begin{array}{c}0.580 \\
(0.210)\end{array}$ \\
\hline $\begin{array}{l}\text { Labor } \\
\text { Supply }\end{array}$ & $\begin{array}{r}1.221= \\
(0.011)\end{array}$ & $\begin{array}{c}0.162^{\circ} \\
(0.018)\end{array}$ & $\begin{array}{r}-3.582^{2} \\
(0.047)\end{array}$ & & & & \\
\hline
\end{tabular}

\begin{abstract}
a: Bignificant at the $1 \%$ level.
b: elgrificant the 5 o level.

c: significant at the $10 \%$ Ievel.
\end{abstract}

Note: The own wage elasticity is defined as $\epsilon_{i, 1}=\left(I_{11} / B_{1}\right)+\beta_{i}-1_{i}$ the

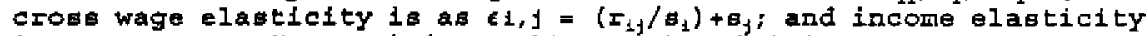
is as $\eta_{1.10 e x}=\left(b_{1 . \text { incond }} / B_{i}\right)+1$. All the elasticities are evaluated at the aample meang. $S_{1}$ is the total expenditure ahare of $i-t h$ input. The atandard errorg are in parentheses. 
TABLE IV- (4)

Estimates of Wage and Income Elasticities of the Allocation of T1me A Household of Male aged 65 and over and Female aged 60 and over

Neither one in the Labor Market

\begin{tabular}{|c|c|c|c|c|c|c|c|}
\hline $\begin{array}{l}\text { Allocatio } \\
\text { of time }\end{array}$ & on $\begin{array}{r}\text { Wit } \\
\text { wrale }\end{array}$ & $\begin{array}{l}\text { Respect } \\
\text { Wfemale }\end{array}$ & $\begin{array}{l}t \text { to } \\
\text { Income }\end{array}$ & $\begin{array}{l}\text { Allocati } \\
\text { of time }\end{array}$ & Wnale & $\begin{array}{l}\text { h Resper } \\
\text { wfemale }\end{array}$ & $\begin{array}{l}\text { ct to } \\
\text { Income }\end{array}$ \\
\hline \multicolumn{4}{|l|}{ Male } & \multicolumn{4}{|l|}{ Female } \\
\hline sleep & $\begin{array}{c}-0.221^{\circ} \\
(0.077)\end{array}$ & $\begin{array}{c}0.161^{b} \\
(0.081)\end{array}$ & $\begin{array}{l}0.713^{\circ} \\
(0.143)\end{array}$ & sleep & $\begin{array}{c}0.158 \\
(0.058)\end{array}$ & $\begin{array}{l}-0.072 \\
(0.061)\end{array}$ & $\begin{array}{r}0.573^{\circ} \\
(0.108)\end{array}$ \\
\hline $\begin{array}{r}\text { Child } \\
\text { Care }\end{array}$ & $\begin{array}{l}-1.664^{b} \\
(0.687)\end{array}$ & $\begin{array}{c}-0.322 \\
(0.726)\end{array}$ & $\begin{array}{c}1.972 \\
(1.286)\end{array}$ & $\begin{array}{l}\text { Child } \\
\text { Care }\end{array}$ & $\begin{array}{r}0.325 \\
(0.205)\end{array}$ & $\begin{array}{c}-0.005 \\
(0.217)\end{array}$ & $\begin{array}{r}0.205 \\
(0.384)\end{array}$ \\
\hline $\begin{array}{l}\text { Medical } \\
\text { Care }\end{array}$ & $\begin{array}{c}0.299 \\
(0.925)\end{array}$ & $\begin{array}{r}0.389 \\
(0.977)\end{array}$ & $\begin{array}{r}0.021 \\
(1.733)\end{array}$ & $\begin{array}{l}\text { Medical } \\
\text { Care }\end{array}$ & $\begin{array}{c}-1.459^{b} \\
(0.636)\end{array}$ & $\begin{array}{l}-1.515^{b} \\
(0.672)\end{array}$ & $\begin{array}{r}4.210^{*} \\
(1.191)\end{array}$ \\
\hline $\begin{array}{l}\text { Radio } \\
\& \mathbf{T V}\end{array}$ & $\begin{array}{l}-0.033 \\
(0.213)\end{array}$ & $\begin{array}{c}0.398^{c} \\
(0.225)\end{array}$ & $\begin{array}{c}0.353 \\
(0.399)\end{array}$ & $\begin{array}{c}\text { Radio } \\
\text { \& TV }\end{array}$ & $\begin{array}{c}-0.085 \\
(0.138)\end{array}$ & $\begin{array}{c}-0.281= \\
(0.146)\end{array}$ & $\begin{array}{r}1.073 \\
(0.258)\end{array}$ \\
\hline
\end{tabular}

a: gignificant at the 1o level.

b: lignificant at the 5 \% level.

c) Ignificant at the 108 level.

Note: The own wage elagticity 1 g defined as $1,1=\left(x_{11} / a_{1}\right)+a_{1}-1$; the

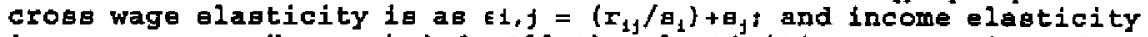
is as $\eta_{1,1 \mathrm{ram}}=\left(\mathrm{b}_{1,1000 \mathrm{~m}} / \theta_{1}\right)+1$. All the elasticitieg are evaluated at the oample meare. $S_{1}$ is the total expenditure ehare of $i-t h$ input. The atandard errors are in parenthoses. 